\title{
Investigation on the Properties of Mortar Containing Palm Oil Fuel Ash and Seashell Powder as Partial Cement Replacement
}

\author{
K. Hasan ${ }^{1}$, F. M. Yahaya ${ }^{1}$, A. Karim², R. Othman ${ }^{1 *}$ \\ ${ }^{1}$ Faculty of Civil Engineering Technology, Universiti Malaysia Pahang, 26300 Gambang,Pahang, Malaysia \\ ${ }^{2}$ Faculty of Chemical and Process Engineering Technology, Universiti Malaysia Pahang, 26300 Gambang,Pahang, Malaysia
}

\begin{abstract}
The concept of utilizing various types of wastes, such as agricultural dumps and marine by-products, as a partial replacement of cement has gained a great interest to develop ecofriendly and economical mortars for sustainable construction. This study aims to evaluate the feasibility of using palm oil fuel ash (POFA), an agro-industrial waste by-product from palm oil mills and seashell powder (SSP) derived from seashells, a marine waste material partial replacement of cement in mortars. The water to binder $(\mathrm{w} / \mathrm{b})$ ratio of 0.49 and the sand to binder $(\mathrm{s} / \mathrm{b})$ ratio of 2.54 with $0 \%$ to $30 \%$ of ordinary portland cement (OPC) by weight was replaced with POFA and SSP, and the resulting mortar samples were tested for mechanical properties and durability in this study. The compressive strength, flexural strength, water absorption, and flow table tests were performed in this study for different percentages of POFA and SSP after 7, 28, and 130 days. The results showed that the 30\% POFA incorporated mortars achieved the highest compressive strength $\left(35.12 \mathrm{~N} / \mathrm{mm}^{2}\right)$, flexural strength $\left(4.06 \mathrm{~N} / \mathrm{mm}^{2}\right)$, high density with less water absorption $(4.79 \%)$ after 130 days of curing and the high strength mortar with less water flow $(22.2 \mathrm{~cm})$ during casting. Also, it found that the 25\% POFA and 5\% SSP incorporated mortars attained acceptable results as supplementary cementing material. This study suggests that the POFA and SSP incorporated mortars could be used in concrete for sustainable development of construction through the efficient valorization of waste materials.
\end{abstract}

ARTICLE HISTORY

Received: $16^{\text {th }}$ July 2021

Revised: 24th July 2021

Accepted: $20^{\text {th }}$ Aug 2021

\section{KEYWORDS}

Palm oil fuel ash;

Seashell powder;

Cement mortar;

Compressive strength;

Flexural strength;

Water absorption;

Flow table test

\section{INTRODUCTION}

Sustainable construction has become a subject of interest in the construction industry nowadays. Concrete, a composite material consisting of cement, water, fine and coarse aggregate, is the most widely produced material for construction. Concrete is the second most consumed material globally after water [1], and three tons of concrete are estimated to use for each human being per year [2]. Concrete use has increased dramatically in recent years, especially in China and Asia. According to the Chatham House $(\mathrm{CH})$ analysis, the globe currently produces 4.4 billion tons of concrete each year, but that amount is predicted to climb almost 5.5 billion tons by 2050 as poorer countries quickly urbanize [3]. In concrete, cement is the costliest constituent that acts as a binding material that hardens over time and joins the aggregates. Cement is the most used material among the concrete components, and global cement production has already surpassed 2.8 billion tons per year [4]. Since 1950, global cement production has expanded by more than 30 -fold and nearly 4-fold since 1990 [5]. Between 2011 and 2013, China used more cement than the United States did throughout the twentieth century [6]. To a significant extent, China generates more than half of the world's cement in the universe, with an expected 2.2 billion metric tons in 2020, followed by India with 340 million metric tons [7]. In 2010 cement production is predicted to upturn from 3.27 billion metric tons to 4.83 billion metric tons by 2030 [8]. Generally, the cement is globally manufactured by combusting traditional materials like stone and clay and industrial by-products such as fly ash and slag. However, the method of producing cement components are very overwhelming energy-wise; it needs to increase the temperature up to $1450{ }^{\circ} \mathrm{C}$, which increase the cement manufacturing cost at the end [9]. Furthermore, it has been indicated that the production of cement is associated with $8 \%$ of carbon dioxide $\left(\mathrm{CO}_{2}\right)$ emission which is contributing to the global climate changes [10]. According to national precast concrete association (NPCA), approximately 0.9 pounds of $\mathrm{CO}_{2}$ is released for every pound of cement produced, as cement is a small part of the mix, a cubic yard of concrete (about $3900 \mathrm{lbs}$.) produces roughly $400 \mathrm{lbs}$. of $\mathrm{CO}_{2}$ [11]. Worrell et al. [12] reported that, cement production accounts for around $5 \%$ of total global anthropogenic $\mathrm{CO}_{2}$ emissions that contributes to global warming. Thus, the traditional concrete industry has a plethora of negative influence on the globe and circumstances. Considering the depletion of natural resources and high energy consumption, the construction industry is motivated to use environment friendly renewable materials that could be utilized as an alternative of ordinary portland cement (OPC). Recently, several research attempts are focused on incorporating agricultural and industrial waste materials into concrete mixes to decrease the use of cement materials [13].

Palm oil fuel ash (POFA), an agro-industrial waste by-product from palm oil mills, is produced from the combustion of various palm oil waste materials, including palm trunks, husks, fibers, oil palm shells, and empty shells fruit bunches [14]. The total global production of POFA is projected to be 12 million tons per year [15]. The palm oil industry generates 
10 million metric tons of waste in Malaysia every year [16]. As a result, the palm oil mills generate million tons of POFA, which are discarded into landfills as waste without proper treatment, and this causes environmental and health hazards [17]. However, POFA could be utilized in the construction components as material as partial replacement of cement [18]. It might be used as cement substitution to obtain better strength than standard concrete due to the silica content in the POFA, which is higher than that of OPC [19]. It was discovered in 2004, Palm oil fuel ash, which had a significant quantity of silica and was crushed to a proper fineness, used to be a pozzolanic material that capable of producing high strength concrete with a 90-day strength of $100 \mathrm{MPa}$ [20]. According to Hamada et al. [21], POFA's major constituent is silicon dioxide $\left(\mathrm{SiO}_{2}\right)$, which ranges from $43 \%$ to $71 \%$ and improves the pozzolanic reaction of high-performance concrete. Thus, it was speculated that, the high quantity of silica would improve the strength and durability of concrete [22]. Alsubari et al. [23] employed treated POFA in the manufacturing of high-replacement-level of self-compacting concrete. Tay [24] looked into the qualities of POFA as a limited cement substitution (ranging from 10\% to 50\%) in order to create a long-lasting concrete. To make lightweight aggregate concrete, Hamada et al. [25] applied POFA with nano particle sizes varying from $0 \%$ to $30 \%$. POFA has a significant effect in decreasing and preventing sulphate assaults, according to Awal and Hussin [26]. POFA was studied by Chindaprasirt [27], who discovered that it has a good potential for concrete production and that replacing OPC with POFA resulted in a slightly higher water demand for a given workability, and that concrete with $20 \%$ ground POFA gained slightly higher compressive strength than conventional concrete. Furthermore, the POFA fineness size gives a better impact to bind and fill the voids among the concrete to produce high strength concrete as it is works as binder and filler [28]. Therefore, before being used, POFA must be processed and sieved to achieve a homogeneous particle size.

Seashell powder (SSP) was derived from the combustion of seashells, a marine waste by-product used as a partial cement alternative for manufacturing sustainable concrete [29]. Generally, the seashells are some of those waste materials that are rapidly accumulating on seashores and landfills. China is the biggest shellfish producer, disposing of ten million tons of waste seashells around in the landfills every year [30]. The European Union has estimated the total output of 600,000 tons of shellfish waste only in 2012 [31]. Every year, the seafood industry generates more than 100 million pounds of seashell waste [32]. Most seashell wastes were primarily dumped in the land fields that cause odour pollution [33]. Additionally, leaving into the public water illegally and reclaimed land may create various problems such as untreatable seashells for a longer period may occur foul odours due to the rotten of remaining flesh within the shells or the decomposition of microbial salts into gases, such as hydrogen sulphide $\left(\mathrm{H}_{2} \mathrm{~S}\right)$, ammonia $\left(\mathrm{NH}_{3}\right)$ and amines [34]. With landfill space rapidly running out, finding new ways to recycle waste has become extremely important. However, a few seashells are used for other purposes, such as fertilizers and handicrafts [35]. Recently, some studies showed that the SSP could be used as one of the ingredients in concrete in the building industry [36]. They can be processed and recycled to substitute fine aggregate, coarse aggregate, filler, or cement [36], [37]. Rahul Rollakanti reported that crushed seashell was replaced by cement at $10 \%, 20 \%$, and $30 \%$, respectively. The results showed that compressive strength was approximately the same at $10 \%$ and gradually dropped as the percentage of seashells was raised [38]. According to Lertwattanaruk et al. [39], using seashell at weights of 5\%,10\%, 15\%, and 20\% as partially replace cement decreases the amount of water used and increases the time that took for the mortar to firm up. Previous studies focused on replacing cement with 5-30\% seashell powder taking longer to set, had lower compressive strength, and had worse flexural strength [39]-[41]. Othman et al. [42] examined that cement was partially replaced with ground cockle by 5-50 \%, wherewith a replacement of more than $15 \%$ by weight of cement causing a 28 -days drop-in concrete strength, permeability, and porosity [42]. Furthermore, typical raw seashells primarily consist of $95 \%$ to $97 \%$ of carbonate calcium $\left(\mathrm{CaCO}_{3}\right)$ that turn into calcium oxide $(\mathrm{CaO})$ once it burns at $600{ }^{\circ} \mathrm{C}$ [43]. $\mathrm{CaO}$ is essential in increasing the production of strength and concrete density [44].

In the last few years, POFA and SSP were widely employed with different percentages as the partial replacement of cement materials to improve the performance of concrete. However, they were separately used in many ways, and further research is still required to obtain adequate strength and durability of concrete. Therefore, the present study was designed to investigate the possibility of using several mixtures of POFA and SSP to replace 0-30\% of OPC (weight \%) in the cement mortar. Furthermore, compressive strength, flexural strength, water absorption, and flow table test were tested to evaluate mortar's mechanical properties and concrete durability.

\section{MATERIALS AND METHODS}

OPC

The sample of OPC, POFA and SSP has been sent to Chemical Laboratory at Centre of Excellence for Advanced Research in Fluid Flow (CARIFF), University Malaysia Pahang (UMP) for chemical analysis using X-ray fluorescence test and the helium pycnometer method was used to determine the specific gravity of fine particles before mixing is prepared. Once the quality of each sample material has passed, then mortar casting commences. Curing age, all harden sample is taken for 7, 28 and 130 days. In this research, for OPC, namely Orang Kuat has been utilized with the strength grade $30 \mathrm{~N} / \mathrm{mm}^{2}$ which followed all the guidelines of ASTM C150-07 type I requirements [45]. The initial and final setting time, Blaine's surface area, and specific gravity of this cement were according to $62 \mathrm{~min}, 138 \mathrm{~min}, 337 \mathrm{~m} / \mathrm{kg}$, and 3.15. In Table 1, the chemical composition of the cement products is summarized. 
POFA was acquired from a local palm oil industry K.K.S Kampung Kuantan BHD, located in Kuantan, Pahang, Malaysia, in an open-air containing moisture and other waste materials. After that, it was dried for 24 hours in an electric oven at $110 \pm 10^{\circ} \mathrm{C}$ temperatures to remove the moisture content. Then, the dry POFA passed through a $300 \mu \mathrm{m}$ sieve to expel all remaining coarse and undesired particles such as the kernels and fiber's that was not completely burnt during the ignition of waste in the palm oil factory. The sieved POFA was then ground using the Los Angeles (LA) Abrasion Machine to get a finer molecule size which could be passed through a $150 \mu \mathrm{m}$ sieve. All unburned carbon which contains in crushed POFA was transferred to an extreme temperature $\left(600^{\circ} \mathrm{C}\right)$ for two hours in an electrical heater to enhance the productivity of POFA by reducing the loss on ignition (LOI) [46]. After burning, POFA was kept in an airtight container independently so that the moisture cannot get inside it.

\section{SSP}

Seashell was collected from nearby Cherating Beach, Kuantan Pahang, Malaysia. As the seashells were collected from the ocean, there was a high possibility that they were polluted by salty water and organic nature. Therefore, they were washed with normal water and afterwards passed again, including vinegar [47]. Then, they were kept outside in daylight to become dry. After drying, the seashells were taken to the concrete laboratory and were crushed into tiny pieces using Los Angeles (LA) Abrasion Machine. After that, they were grounded with a blender and sieved by $150 \mu \mathrm{m}$ sieve to obtain SSP. By burning the SSP at a high temperature around $500^{\circ} \mathrm{C}$ to $600^{\circ} \mathrm{C}$ for 3 days $\mathrm{CaCO}_{3}$ is converted to $\mathrm{CaO}$ and carbon (c) and remove all the moisture among the particles [48], [49].

\section{Fine Aggregate}

The ordinary sand, also called fine aggregate utilized in this research, was bought from a top-notch local quarry. The aggregates were air-dried and sieved using a mechanical shaker to identify the grading of fine aggregates. The particles size of fine aggregate between the range of 0.3 and $4.75 \mathrm{~mm}$; the water absorption, specific gravity, and fineness modulus of the acceptable sum were $0.78 \%, 2.75$, and 2.79 , respectively.

\section{Water}

In a mortar, production water is a fundamental source. Subsequently, the quality of water is significant as contaminants can unfavourably influence the strength of the mortar. During the pozzolanic activity and hydration process, cement requires adequate water to produce calcium silicate gel (C-S-H) [50]. As the outcome, the water utilized for making and curing could be sensibly neat and clean and free from harmful components, such as acid, oil, salt, residue, and different components that may be adverse to the concrete. In this examination, portable tap used water provided from Jabatan Bekalan Air Pahang.

\section{Chemical Properties}

Before being employed in the tests, the chemical characteristics of the OPC, POFA, and SSP samples were examined, as shown in Table 1. The chemical compositions of OPC, POFA, and SSP were determined using X-ray fluorescence, a non-destructive method used to a wide range of materials chemical composition analysis at Centre of Excellence for Advanced Research in Fluid Flow (CARIFF) Chemical Laboratory, University Malaysia Pahang (UMP).

Table 1. Chemical properties of ordinary portland cement, palm oil fuel ash and seashell powder

\begin{tabular}{llll}
\hline Chemical & OPC $(\%)$ & POFA (\%) & SSP $(\%)$ \\
\hline Silicon Dioxide $\left(\mathrm{SiO}_{2}\right)$ & 28.20 & 53.82 & 3.65 \\
Aluminum oxide $\left(\mathrm{Al}_{2} \mathrm{O}_{3}\right)$ & 4.90 & 5.66 & 1.15 \\
Ferric oxide $\left(\mathrm{Fe}_{2} \mathrm{O}_{3}\right)$ & 2.50 & 4.54 & 0.20 \\
Calcium oxide $(\mathrm{CaO})$ & 50.40 & 4.24 & 52.34 \\
Magnesium oxide $(\mathrm{MgO})$ & 3.10 & 3.19 & 0.42 \\
Potassium Oxide $\left(\mathrm{K}_{2} \mathrm{O}\right)$ & 0.40 & 4.47 & 0.13 \\
Sulphur Oxide $\left(\mathrm{SO}_{3}\right)$ & 2.30 & 2.25 & 0.47 \\
Sodium Oxide $\left(\mathrm{Na}_{2} \mathrm{O}\right)$ & 0.20 & 0.10 & 0.35 \\
Loss on Ignition $(\mathrm{LOI})$ & 2.40 & 10.49 & 41.25 \\
\hline
\end{tabular}

OPC-ordinary portland cement, POFA-palm oil fuel ash, and SSP-seashell powder. 


\section{Pre-mixing Experiment}

Pre-mixing experiments are important to observe the eligibility of concrete. Before concrete casting, there are certain things to be considered: moisture content, mixing procedures, and the size of the concrete mould. Portland cement type I was substituted by POFA and SSP at the range of $0 \%, 5 \%, 10 \%, 15 \%, 20 \%, 25 \%$ and $30 \%$ by total binder weight. Throughout the study, the water to binder $(\mathrm{w} / \mathrm{b})$ ratio of 0.49 and the sand to binder $(\mathrm{s} / \mathrm{b})$ ratio of 2.54 was employed and kept constant. The mixture specimen's size of mortar beam $(40 \times 40 \times 160) \mathrm{mm}^{3}$ for flexural strength test and specimen's size of mortar cube $(40 \times 40 \times 40) \mathrm{mm}^{3}$ for compressive strength test were prepared. The cast samples were secured with plastic to counteract water passing. After casting, kept the concrete specimens for 24 hour and then the specimens were expelled from the mould. From that point, they were immersed into normal water at a temperature of $23 \pm 2{ }^{\circ} \mathrm{C}$ for 7,28 , and 130 days. Mechanical properties such as flexural strength and compressive strength tests were performed after each ageing period. The water absorption test was conducted after 130 days. The mixture proportions for cube of mortar paste containing palm oil fuel ash and seashell powder are presented in Table 2.

Table 2. The mixture proportions of ordinary portland cement, palm oil fuel ash, seashell powder, sand and water for mortar cube specimens

\begin{tabular}{llllll}
\hline Mix Proportion $\left(\boldsymbol{k g} / \mathbf{m}^{\mathbf{3}}\right)$ & OPC & POFA & SSP & Sand & Water \\
\hline Control Mix & $100 \%$ & - & - & $100 \%$ & 0.379 \\
SSP 30\% & $70 \%$ & - & $30 \%$ & $100 \%$ & 0.379 \\
POFA 5\%, SSP 25\% & $70 \%$ & $5 \%$ & $25 \%$ & $100 \%$ & 0.379 \\
POFA 10\%, SSP 20\% & $70 \%$ & $10 \%$ & $20 \%$ & $100 \%$ & 0.379 \\
POPA 15\%, SSP 15\% & $70 \%$ & $15 \%$ & $15 \%$ & $100 \%$ & 0.379 \\
POFA 20\%, SSP 10\% & $70 \%$ & $20 \%$ & $10 \%$ & $100 \%$ & 0.379 \\
POPA 25\%, SSP 5\% & $70 \%$ & $25 \%$ & $5 \%$ & $100 \%$ & 0.379 \\
POFA 30\% & $70 \%$ & $30 \%$ & - & $100 \%$ & 0.379 \\
\hline
\end{tabular}

OPC-ordinary Portland cement, POFA-palm oil fuel ash, and SSP-seashell powder.

\section{Flow-Table Test}

According to ASTM C109, The standard mortar's ingredient proportions are one part cement to 2.75 parts graded standard sand by weight. For all Portland cements, use a water-to-cement ratio of 0.485 , and for all air-entraining portland cement, use a ratio of 0.460 [51]. The flow table test of cement mortars was carried out to estimate the amount of water necessary for gauging to perform a strength test. In the case of a compressive strength test of mortar concrete, the volume of water used for gauging must be sufficient to achieve a flow of $110 \pm 5 \%$ with 25 drops in 15 second. The experimented test is appeared in Figure 1.
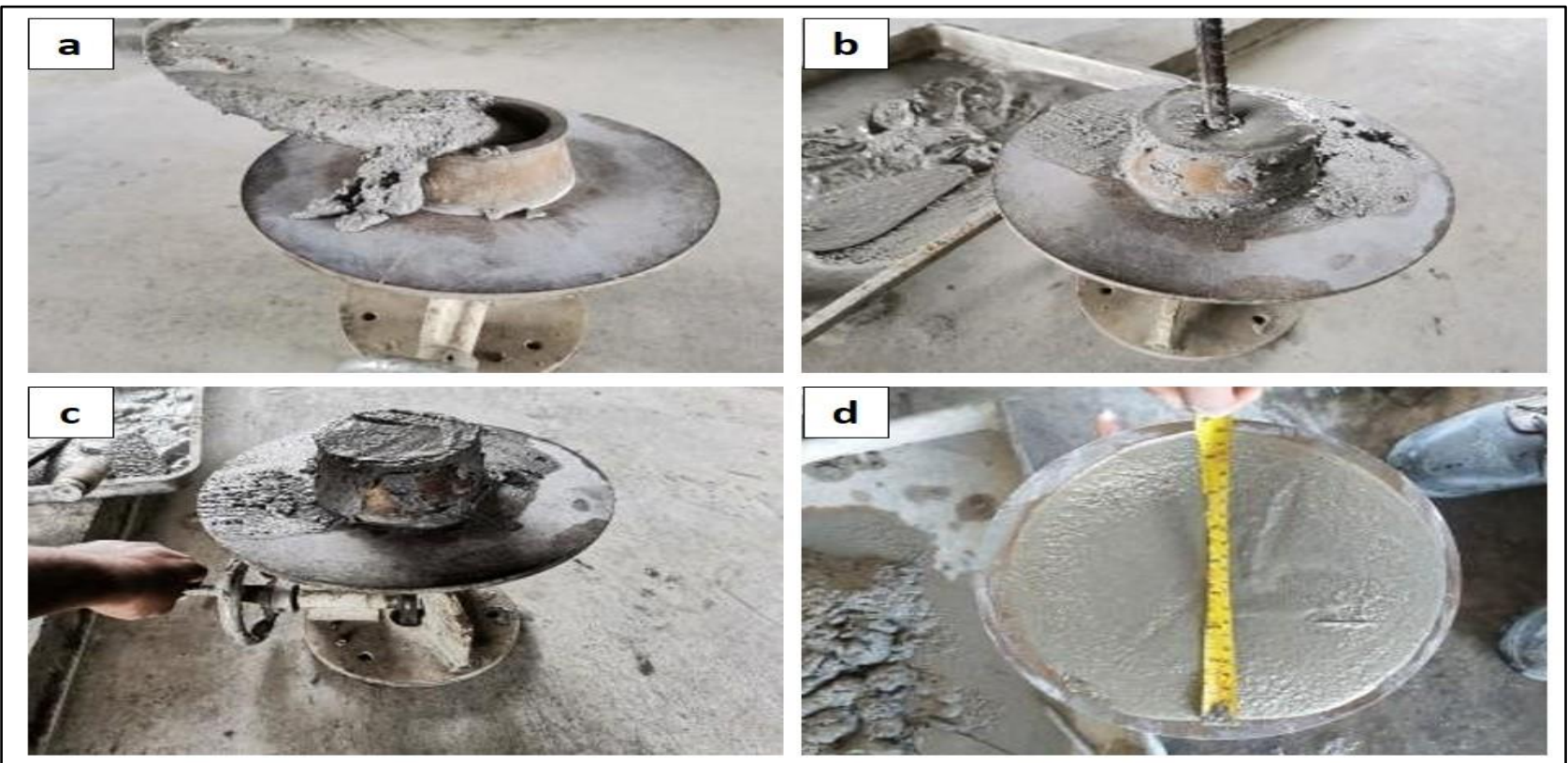

Figure 1. - (a) Fill up the cone with concrete, (b) Concrete tamping using a tamping rod, (c) 25 drops in 15 seconds, (d) Measurement of concrete flow 


\section{Compressive Strength}

Seventy-two cubes in size $(40 \times 40 \times 40) \mathrm{mm}^{3}$ were utilized to estimate the mortar compressive strength. The compression test was conducted using ADR Auto V2 $2000 \mathrm{KN}$ compression machine with a pacing rate of $2.40 \mathrm{KN} / \mathrm{s}$. The pace loading was continually applied unless the samples were noticeably broken and the machine stopped the strength counting. The compressive strength was resolved following 7, 28 and 130 days of curing within water for every specimen. In Figure 2 the conducted experiment appears appropriately.

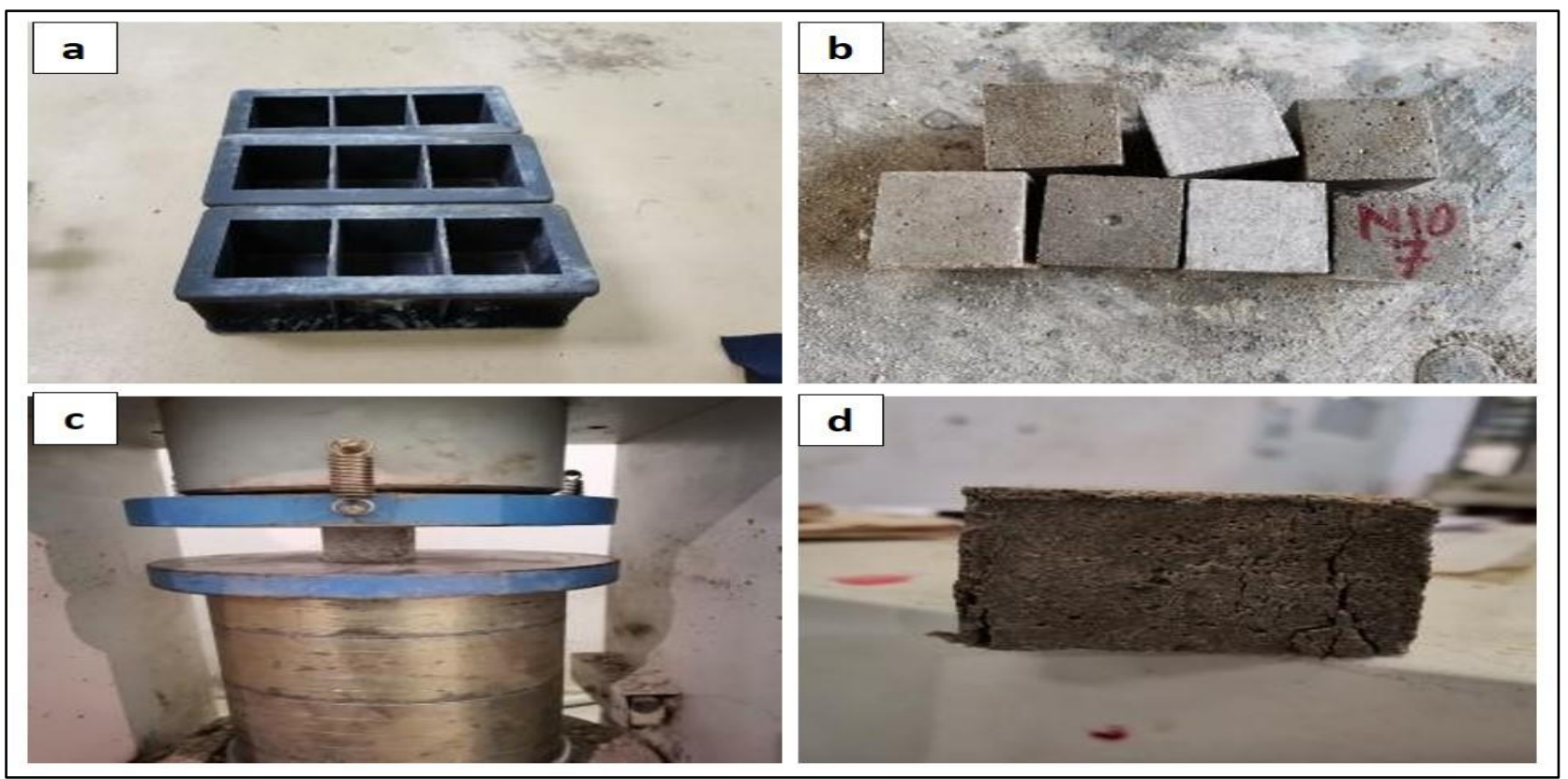

Figure 2. - (a) Concrete cube mould, (b) Concrete cubes after curing, (c) Compressive strength test (d) Fail concrete sample

\section{Flexural Strength}

In flexural strength test, three-point bending was used, and uniaxial compression was conducted at 7,28 and 130 days on mortar samples, shown in Figure 3. After a one-day curing period, the specimens were maintained in water at $25^{\circ} \mathrm{C}$ for 7, 28, and 130 days, respectively, before being tested. A bending test in the three points was conducted on a beam sample $(40 \times 40 \times 160) \mathrm{mm}^{3}$ following ASTM C348 [52].

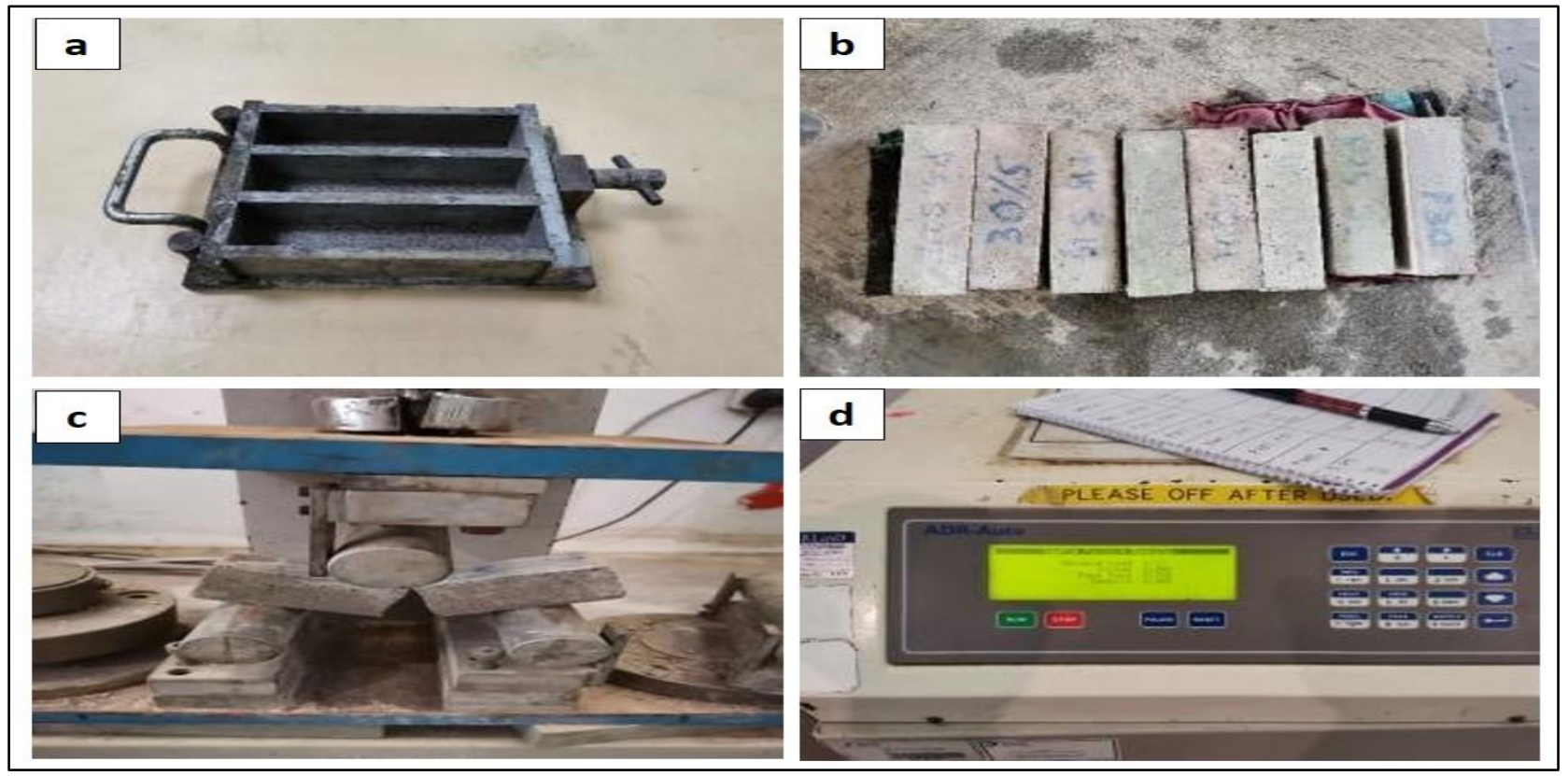

Figure 3. (a) Concrete beam mould, (b) Beam after curing, (c) Beam testing, (d) Data collection from compression machine 


\section{Water Absorption}

A water absorption test was conducted after 130 days of curing, as shown in Figure 4. According to ASTM C642, for the estimation of sample porosity, the water absorption test was carried out for the same size of beam sample $(40 \times 40$ $\times 160) \mathrm{mm}^{3}$ [53]. The specimens were taken out from the immerged tank and dried inside the oven for 48 hours. After that, the samples were kept out from the oven and made cold in a sealed container for 24 hours. Once finished with the cooling process, the sample was weighted. The specimens were fully immersed in the water, almost $25 \mathrm{~mm}$ below the water surface. After 10 minutes, the specimens were taken out from the tank, wiped out the water, and then weighed. Similarly, the specimens weighed after 30 and 60 minutes were immersed in the water tank. Finally, the degree of water absorption was calculated using Equation 1.

$$
\text { Degree of absorption }=\left[\frac{M F-M I}{M I}\right] x 100
$$

Where MF = after immerged final weight of specimens; $\mathrm{MI}=$ after dried up initial weight of specimens.
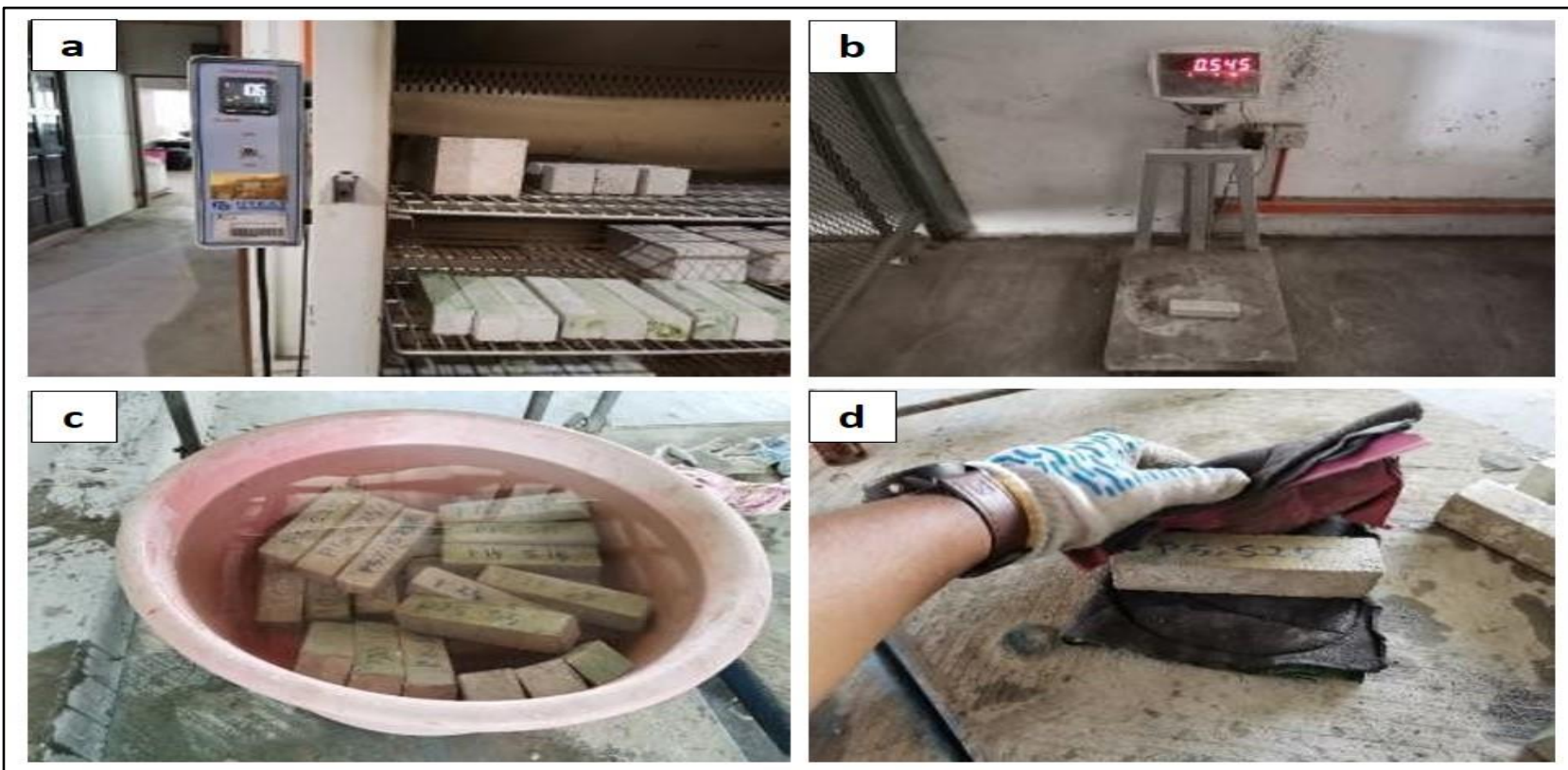

Figure 4. (a) Sample drying inside the oven, (b) Taking weight after drying, (C) Immerse sample inside the water,

(d) Wipe water from the immerse sample

\section{RESULT AND DISCUSSION}

\section{Flow-Table Test}

Flow table test was performed to determine the amount of water required for gauging during masonry cement strength tests and is presented in Figure 5. It can be seen that the flow of concrete mix was significantly increased from $23 \mathrm{~cm}$ to $23.5 \mathrm{~cm}$ while $30 \%$ of OPC was replaced by SSP, which was higher than that of the control mix. This could be attributed to the decreased mix density with an increased amount of SSP in the concrete mix [37]. This is because the presence of $\mathrm{CaCO}_{3}$ in SSP more than OPC which reduces the density of the concrete that increase the amount of concrete paste [54]. Moreover, the replacement of 5\% POFA and 25\% SSP mix in the concrete could achieve a satisfactory flow rate that was almost equal to the control mixture. 


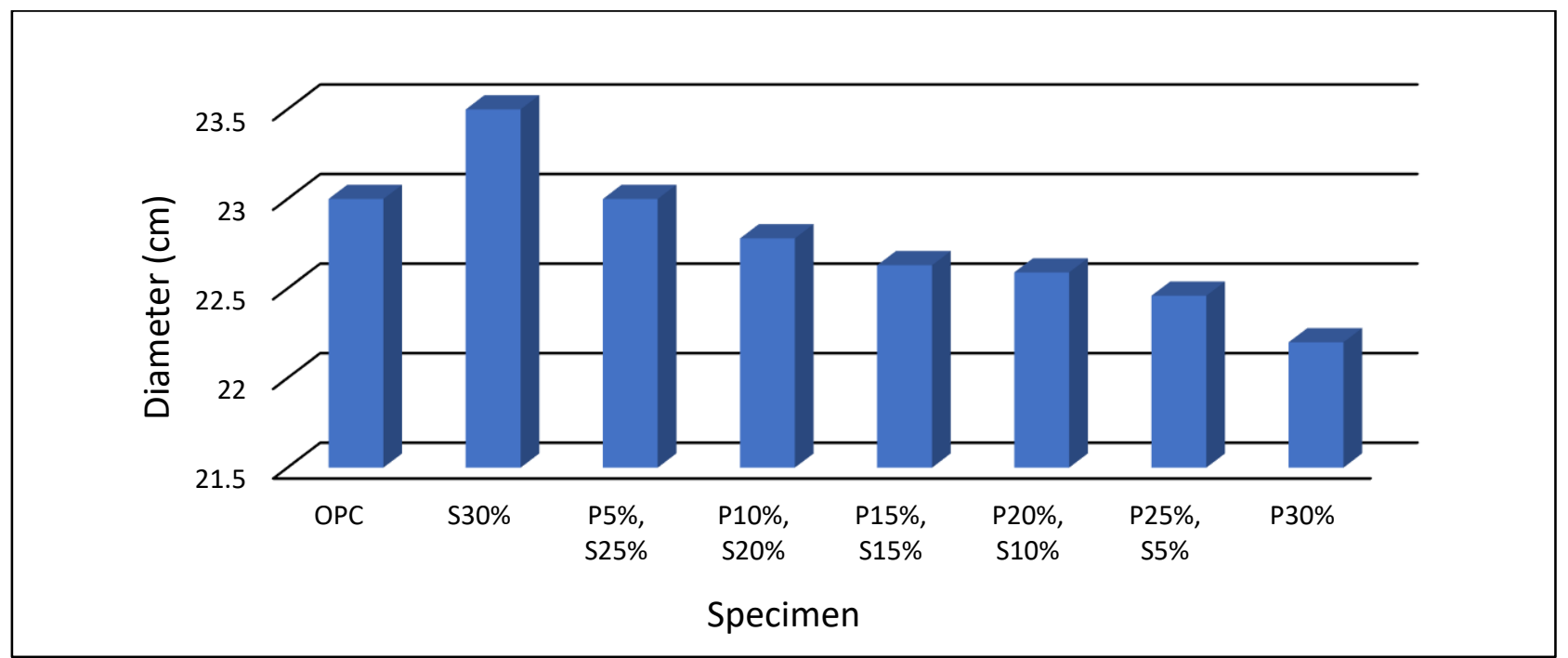

Figure 5. Concrete flow for various \% replacement of POFA and SSP at different age. OPC- ordinary portland cement, $\mathrm{P}$ - palm oil fuel ash, S- seashell powder

Besides, the flow rate of the concrete was decreased with the increased amount of POFA in the mixtures. This is due to the higher fineness of POFA, which has a larger surface area and can absorb more water, workability decreases as the concentration of POFA increases [55]-[58]. Another reason for the decreasing flow rate could be the higher water absorbing capacity of POFA. The particles are more porous than OPC, and their surface roughness and angularity led to the loss of part of the mixing water and, consequently, decreased flow rate. Furthermore, the high carbon concentration of the POFA contributes to the mix's reduced workability [59].

\section{Compressive Strength}

A compressive strength test applying a push force to both sides of the concrete specimen determines the maximum compression that concrete can withstand without failure. The development of concrete strength for various mixtures of POFA-SSP was evaluated and is presented in Figure 6. The highest compressive strength of $35.12 \mathrm{~N} / \mathrm{mm}^{2}$ was obtained for control mix design of OPC after in 130 days curing age while the maximum compressive strength of $34.03 \mathrm{~N} / \mathrm{mm}^{2}$ mix was found at the same curing age for 30\% POFA replacement. Furthermore, the compressive strength was increased with POFA content from 5\% to $30 \%$ replacement accordingly. This is because the silica concentration of POFA can be raised by burning and grinding further, which will boost the concrete's compressive strength [60]. At the early age of curing, the concrete mixtures with cement lead to the reduced compressive strength of concrete. The concrete mixtures with POFA play an influential role in compressive strength development as it has pozzolanic reaction [61].

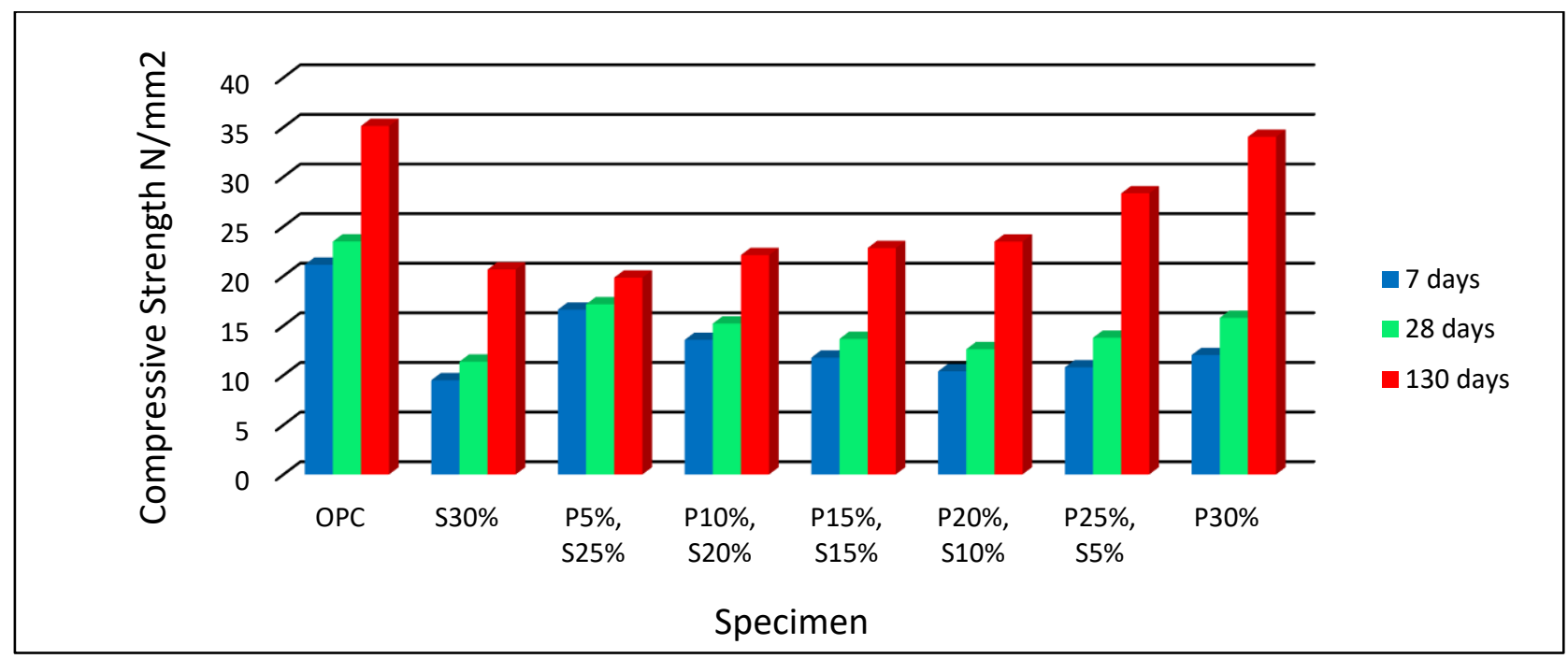

Figure 6. The Compressive strength for various \%replacement of POFA and SSP at different age. OPC- ordinary Portland cement, P- palm oil fuel ash, S- seashell powder

The lowest compressive strength of $19.84 \mathrm{~N} / \mathrm{mm}^{2}$ was obtained in 130 days when the mixture was with 5\% POFA and $25 \%$ SSP. In addition, the concrete with a high amount of SSP 30\% which was achieved the lowest compressive strength $9.5 \mathrm{~N} / \mathrm{mm}^{2}$ at the early age of curing. This was most likely due to a drop in cement content, which slowed the 
rate of hydration in early concrete. Because the seashell has less $\mathrm{CaO}$ than cement, the process is disrupted, resulting in slow hydration [62]. The compressive strength of mortar mix with the addition of SSP was gradually increased after 7 and 28 days, where the dramatic increase ware found with the addition of POFA. Many of these studies have shown that concretely reduces the early strength due to an increase in SSP [63]. Probably, this reduction is due to the presence of $\mathrm{CaO}$ within SSP that would react with $\mathrm{Al}_{2} \mathrm{O}_{3}$ and gypsum, so that the reaction decrease the early hydration of alite [64].

\section{Flexural Strength}

The flexural strength of different specimens ware measured to observe the tensile strength of the concrete and is shown in Figure 7. It can be appeared that the flexural strength was varied in the range of $1.64 \mathrm{~N} / \mathrm{mm}^{2}$ to $4.06 \mathrm{~N} / \mathrm{mm}^{2}$ and it was observed to improve for all mixes according to the increasing curing age at 7, 28 and 130 days. It was examined that the $30 \%$ POFA with mortar mix achieved a flexural strength of $2.10,2.44,4.06 \mathrm{~N} / \mathrm{mm}^{2}$ on 7, 28, and 130 days of curing, which was higher than the control mix. This is happening due to the pozzolanic reaction of POFA, which increase the concrete strength compared to the control mix [65]. POFA has a large percentage of amorphous $\mathrm{SiO}_{2}$ which is shown in Table 1 and it react with calcium hydroxide $\left(\mathrm{Ca}(\mathrm{OH})_{2}\right)$ created during the hydration process to produce more calcium silicate hydrate $(\mathrm{C}-\mathrm{S}-\mathrm{H})$ gel compound and contribute greater strength to the concrete by filling capillary pores and improving interfacial bonding between aggregates and pastes at later ages. [66]. Furthermore, the flexural strength was observed to be improved for longer curing age with POFA content.

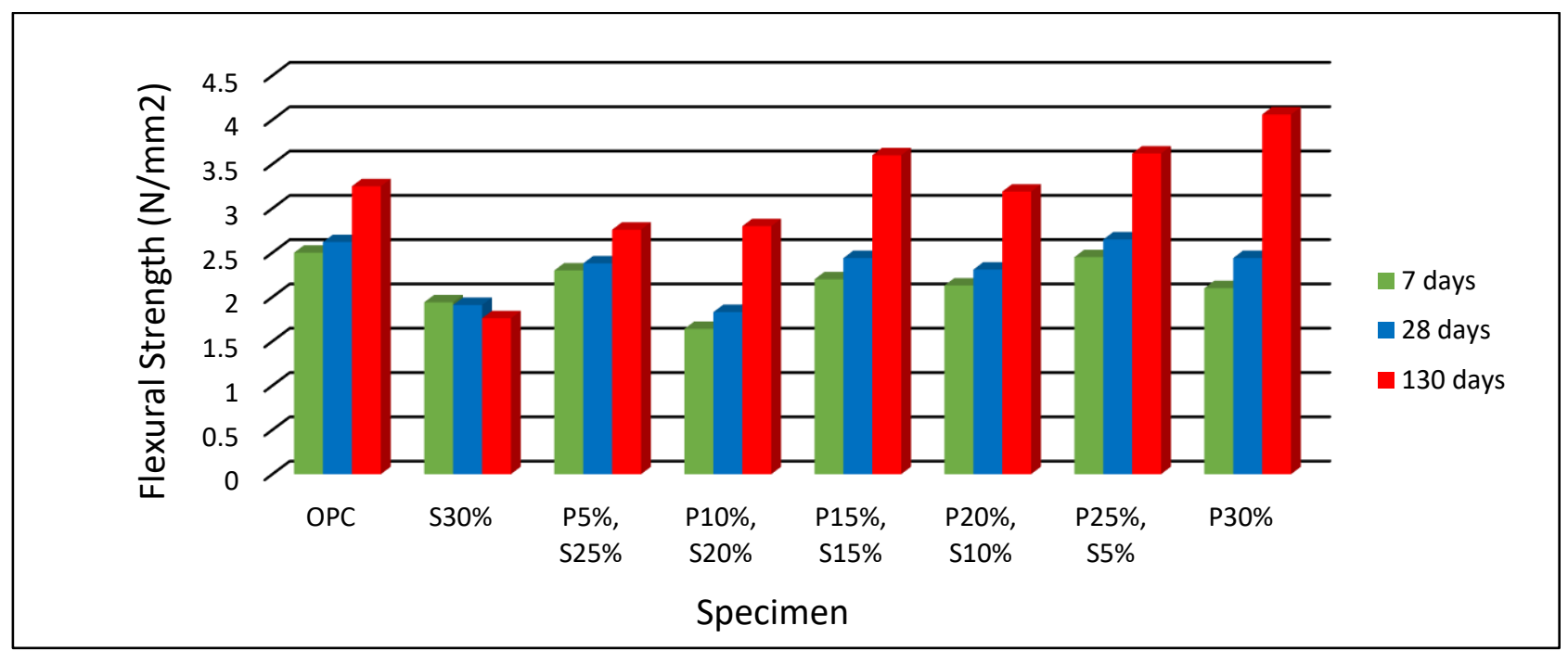

Figure 7. The Flexural strength for various \%replacement of POFA and SSP at different age. OPC- ordinary Portland cement, P- palm oil fuel ash, S- seashell powder

The value of the flexural strength decrease for increased curing age in the OPC with $30 \%$ SSP mortar mix. This is because the shape of SSP plays a vital role in reducing the flexural strength of the beam [67]. Moreover, from this graph, the flexural strength of concrete mix started to increase with a decrease in the percentage of SSP and got an adequate flexural strength at 5\% SSP and 25\% POFA mix.

\section{Water Absorption}

A water absorption test was performed for all concrete samples to evaluate concrete's water tightness and is presented in Figure 8. Generally, the rate at which harmful agents penetrate concrete near an exposed surface determines the concrete's durability. The sorptivity of concrete is influenced by its permeability and porosity, as well as the strength of capillary forces. The result has shown that the substitution for 30\% of POFA has the lowest percentage of absorption. This is because $\mathrm{CaO}$ remains in POFA, which react with the water. The incorporation of POFA by $30 \%$ was the best cement replacement in our study, meaning that the pozzolanic reaction had occurred, so the quantity of C-S-H gel in the concrete mix might be higher. As known, the C-S-H gel is liable for filling up the voids and capillary pores in the concrete structure. The fewer water molecules may be able to enter. That is why $30 \%$ POFA had less water absorption possibility [68].

Moreover the POFA particles produce more porous and had a higher specific surface area than cement, resulting in pore structure densification due to pozzolanic processes. Additionally, due to pore refinement, POFA minimizes pore diameters in lightweight concrete [69]. However, the percentage of water absorption is relatively high in 15\% POFA and $15 \%$ SSP compared to the control mix. 


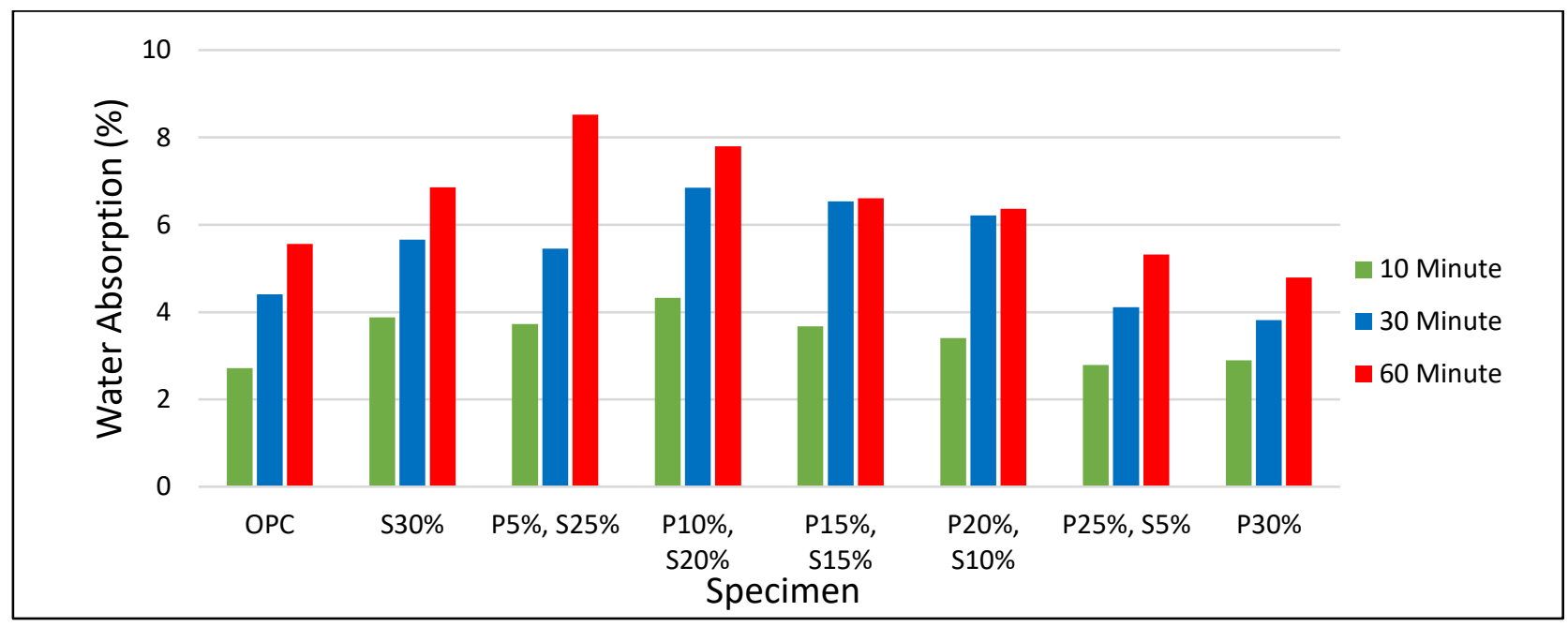

Figure 8. Water absorption for various \%replacement of POFA and SSP at different age. OPC- ordinary Portland cement, P- palm oil fuel ash, S- seashell powder

On the contrary, the adsorption capacity of shell powder rose as the shell particle size decreased, reducing the concrete's durability [70]. The figure showed that the concrete mix with 5\% POFA and 25\% SSP as a partial alternative to OPC has the highest water absorption rate compared to the OPC mix at $60 \mathrm{~min}$. This might be due to the high amount of porosity within the specimen [71]. Moreover, with less amount of pozzolanic content, which was not enough to fill up the voids and capillary pores in this sample, as a result, more water molecules were diffused into the specimen.

\section{CONCLUSION}

In this study, several investigations were carried out to find the performance of POFA and SSP on the concrete mechanical properties and water absorption as partial cement replacement. The goal was to replace $30 \%$ of the cement by weight and experimentally test the newly generated mixtures. The following conclusion can be drawn based on the given results and the above discussion:

The flow table test results show that the addition of POFA decreases the concrete flow where increasing the SSP content in the mix appears opposite effect. Moreover, adding 5\% POFA and 25\% SSP in concrete achieved similar workability as the control mix. The optimum compressive strength of $34.03 \mathrm{~N} / \mathrm{mm}^{2}$ was obtained for $30 \%$ POFA replacement at the curing age of 130 days, which was almost similar to the control mix $\left(35.12 \mathrm{~N} / \mathrm{mm}^{2}\right)$. Besides, using $5 \%$ SSP and 25\% POFA could be achieved an acceptable value of compressive strength $\left(28.33 \mathrm{~N} / \mathrm{mm}^{2}\right)$ in the concrete mix. The highest flexural strength of $4.06 \mathrm{~N} / \mathrm{mm}^{2}$ was observed for 30\% POFA replacement at 130 days curing age while the control mix obtained $3.25 \mathrm{~N} / \mathrm{mm}^{2}$. Furthermore, 5\% SSP and 25\% POFA addition has an admissible strength $\left(3.62 \mathrm{~N} / \mathrm{mm}^{2}\right)$ which is more than plane concrete. In contrast, $30 \%$ SSP in the concrete mix provides the lowest flexural strength compared to other specimens. Nevertheless, the water absorption test for the concrete containing 30\% POFA replacement witnessed less water absorption, which indicates the high density of concrete. This is due to the pozzolanic reaction, which changed the pore size structure of the mix from coarse to fine, reducing the amount of water that enters the concrete. In opposed to, 25\% SSP: 5\% POFA addition in the concrete mix shows the highest absorption possibility, indicating the low density of the concrete structure. Finally, the findings of this study showed that a specific range of POFA and SSP incorporation in mortars could be employed in concrete for long-term construction development by maximising the value of waste materials.

\section{REFERENCES}

[1] "Can concrete keep up its popularity? - Building Products," 2019. https://buildingproducts.co.uk/can-concrete-keep-popularity/ (accessed Jun. 27, 2021).

[2] C. R. Gagg, "Cement and concrete as an engineering material: An historic appraisal and case study analysis," Eng. Fail. Anal., vol. 40, pp. 114-140, 2014, doi: 10.1016/j.engfailanal.2014.02.004.

[3] "Concrete production produces eight percent of the world's carbon dioxide emissions," 2019. https://www.archpaper.com/2019/01/concrete-production-eight-percent-co2-emissions/ (accessed Jun. 27, 2021).

[4] G. Habert, "Assessing the environmental impact of conventional and 'green' cement production," in Eco-Efficient Construction and Building Materials: Life Cycle Assessment (LCA), Eco-Labelling and Case Studies, Elsevier Inc., 2013, pp. 199-238.

[5] R. M. Andrew, "Global CO 2 emissions from cement production," Earth Syst. Sci. Data, vol. 10, pp. 195-217, 2018, doi: 10.5194/essd-10-195-2018.

[6] "The Popularity of Concrete - Alabama Concrete Industries Association," 2019. https://alconcrete.org/blog/the-popularity-ofconcrete/ (accessed Jun. 27, 2021). 
[7] "Worldwide Cement Production From 2015 to 2019 | Datis Export Group," 2020. https://datis-inc.com/blog/worldwidecement-production-from-2015-to-2019/ (accessed Jun. 27, 2021).

[8] H. V. Oral and H. Saygin, "Simulating the future energy consumption and greenhouse gas emissions of Turkish cement industry up to 2030 in a global context," Mitig. Adapt. Strateg. Glob. Chang., vol. 24, no. 8, pp. 1461-1482, Dec. 2019, doi: 10.1007/s11027-019-09855-8.

[9] N. Mahasenan, S. Smith, and K. Humphreys, "The Cement Industry and Global Climate ChangeCurrent and Potential Future Cement Industry CO2 Emissions," in Greenhouse Gas Control Technologies - 6th International Conference, Elsevier, 2003, pp. 995-1000.

[10] L. Rodgers, "Climate change: The massive CO2 emitter you may not know about," BBC News, no. December 2018. p. Science, 2018.

[11] "Concrete and CO2 - National Precast Concrete Association," 2013. https://precast.org/2013/05/concrete-and-co2/ (accessed Jun. 28, 2021).

[12] E. Worrell, L. Price, N. Martin, C. Hendriks, and L. O. Meida, "CARBON DIOXIDE EMISSIONS FROM THE GLOBAL CEMENT INDUSTRY *," 2001. Accessed: Jun. 28, 2021. [Online]. Available: www.annualreviews.org.

[13] M. Sandanayake, Y. Bouras, R. Haigh, and Z. Vrcelj, "Current sustainable trends of using waste materials in concrete-a decade review," Sustain., vol. 12, no. 22, pp. 1-38, 2020, doi: 10.3390/su12229622.

[14] M. J. A. Mijarsh, M. A. Megat Johari, and Z. A. Ahmad, "Synthesis of geopolymer from large amounts of treated palm oil fuel ash: Application of the Taguchi method in investigating the main parameters affecting compressive strength," Constr. Build. Mater., vol. 52, pp. 473-481, Feb. 2014, doi: 10.1016/j.conbuildmat.2013.11.039.

[15] H. M. Hamada et al., "Sustainable use of palm oil fuel ash as a supplementary cementitious material: A comprehensive review," Journal of Building Engineering, vol. 40. Elsevier Ltd, p. 102286, Aug. 01, 2021, doi: 10.1016/j.jobe.2021.102286.

[16] M. Ayub et al., "Promoting sustainable cleaner production paradigms in palm oil fuel ash as an eco-friendly cementitious material: A critical analysis," Journal of Cleaner Production, vol. 295. Elsevier Ltd, p. 126296, May 01, 2021, doi: 10.1016/j.jclepro.2021.126296.

[17] K. H. Yang, J. K. Song, and K. Il Song, "Assessment of CO 2 reduction of alkali-activated concrete," J. Clean. Prod., vol. 39, pp. 265-272, Jan. 2013, doi: 10.1016/j.jclepro.2012.08.001.

[18] A. Munir, Abdullah, Huzaim, Sofyan, Irfandi, and Safwan, "Utilization of palm oil fuel ash (POFA) in producing lightweight foamed concrete for non-structural building material," in Procedia Engineering, Jan. 2015, vol. 125, pp. 739-746, doi: 10.1016/j.proeng.2015.11.119.

[19] L. A. Sofri et al., "Performance of Concrete by Using Palm Oil Fuel Ash (POFA) as a Cement Replacement Material," Appl. Mech. Mater., vol. 815, pp. 29-33, Nov. 2015, doi: 10.4028/www.scientific.net/amm.815.29.

[20] V. Sata, C. Jaturapitakkul, and K. Kiattikomol, "Utilization of Palm Oil Fuel Ash in High-Strength Concrete," J. Mater. Civ. Eng., vol. 16, no. 6, pp. 623-628, Dec. 2004, doi: 10.1061/(ASCE)0899-1561(2004)16:6(623).

[21] H. M. Hamada et al., "Sustainable use of palm oil fuel ash as a supplementary cementitious material: A comprehensive review," J. Build. Eng., vol. 40, p. 102286, Aug. 2021, doi: 10.1016/J.JOBE.2021.102286.

[22] N. K. Amudhavalli and J. Mathew, "EFFECT OF SILICA FUME ON STRENGTH AND DURABILITY PARAMETERS OF CONCRETE," 2012.

[23] B. Alsubari, P. Shafigh, and M. Z. Jumaat, "Utilization of high-volume treated palm oil fuel ash to produce sustainable selfcompacting concrete," J. Clean. Prod., vol. 137, pp. 982-996, Nov. 2016, doi: 10.1016/J.JCLEPRO.2016.07.133.

[24] J. Tay, "Ash from OilPalm Waste as a Concrete Material," J. Mater. Civ. Eng., vol. 2, no. 2, pp. 94-105, May 1990, doi: 10.1061/(ASCE)0899-1561(1990)2:2(94).

[25] H. M. Hamada, F. M. Yahaya, K. Muthusamy, G. A. Jokhio, and A. M. Humada, "Fresh and hardened properties of palm oil clinker lightweight aggregate concrete incorporating Nano-palm oil fuel ash," Constr. Build. Mater., vol. 214, pp. 344-354, Jul. 2019, doi: 10.1016/J.CONBUILDMAT.2019.04.101.

[26] A. S. M. A. Awal and M. W. Hussin, "The effectiveness of palm oil fuel ash in preventing expansion due to alkali-silica reaction," Cem. Concr. Compos., vol. 19, no. 4, pp. 367-372, Jan. 1997, doi: 10.1016/S0958-9465(97)00034-6.

[27] P. Chindaprasirt, S. Homwuttiwong, and C. Jaturapitakkul, "Strength and water permeability of concrete containing palm oil fuel ash and rice husk-bark ash," Constr. Build. Mater., vol. 21, no. 7, pp. 1492-1499, Jul. 2007, doi: 10.1016/J.CONBUILDMAT.2006.06.015.

[28] A. S. M. Abdul Awal and I. Abubakar, "PROPERTIES OF CONCRETE CONTAINING HIGH VOLUME PALM OIL FUEL ASH: A SHORT-TERM INVESTIGATION," 2011. doi: 10.11113/MJCE.V23.15818.

[29] M. Olivia, A. A. Mifshella, and L. Darmayanti, "Mechanical properties of seashell concrete," in Procedia Engineering, Jan. 2015, vol. 125, pp. 760-764, doi: 10.1016/j.proeng.2015.11.127.

[30] A. Abdelouahed, H. Hebhoub, L. Kherraf, and M. Belachia, "Effect of Cockele Shells on Mortars Performance in Extreme Conditions," Civ. Environ. Eng. Reports, vol. 29, no. 2, pp. 60-73, Jun. 2019, doi: 10.2478/ceer-2019-0017.

[31] Fao, "GLOBEFISH RESEARCH PROGRAMME Food and Agriculture Organization of the United Nations Products The European market for mussels Volume 115," 2014.

[32] A. Perea, T. Kelly, and Y. Hangun-Balkir, "Utilization of waste seashells and Camelina sativa oil for biodiesel synthesis," Green Chemistry Letters and Reviews, vol. 9, no. 1. Taylor and Francis Ltd., pp. 27-32, Jan. 02, 2016, doi: 10.1080/17518253.2016.1142004. 
[33] J. Lu, X. Cong, Y. Li, Y. Hao, and C. Wang, "Scalable recycling of oyster shells into high purity calcite powders by the mechanochemical and hydrothermal treatments," J. Clean. Prod., vol. 172, pp. 1978-1985, Jan. 2018, doi: 10.1016/j.jclepro.2017.11.228.

[34] D. Suarez-Riera, A. Merlo, L. Lavagna, R. Nisticò, and M. Pavese, "Mechanical properties of mortar containing recycled Acanthocardia tuberculata seashells as aggregate partial replacement," Bol. la Soc. Esp. Ceram. y Vidr., Apr. 2020, doi: 10.1016/j.bsecv.2020.03.011.

[35] K. H. Mo, U. J. Alengaram, M. Z. Jumaat, S. C. Lee, W. I. Goh, and C. W. Yuen, "Recycling of seashell waste in concrete: A review," Construction and Building Materials, vol. 162. Elsevier Ltd, pp. 751-764, Feb. 20, 2018, doi: 10.1016/j.conbuildmat.2017.12.009.

[36] B. A. Tayeh, M. W. Hasaniyah, A. M. Zeyad, and M. O. Yusuf, "Properties of concrete containing recycled seashells as cement partial replacement: A review," Journal of Cleaner Production, vol. 237. Elsevier Ltd, p. 117723, Nov. 2019, doi: 10.1016/j.jclepro.2019.117723.

[37] U. G. Eziefula, J. C. Ezeh, and B. I. Eziefula, "Properties of seashell aggregate concrete: A review," Construction and Building Materials, vol. 192. Elsevier Ltd, pp. 287-300, Dec. 20, 2018, doi: 10.1016/j.conbuildmat.2018.10.096.

[38] C. Rahul Rollakanti, C. Venkata Siva Rama Prasad, K. K. Poloju, N. M. Juma Al Muharbi, and Y. Venkat Arun, "An experimental investigation on mechanical properties of concrete by partial replacement of cement with wood ash and fine sea shell powder," Mater. Today Proc., vol. 43, pp. 1325-1330, Jan. 2021, doi: 10.1016/J.MATPR.2020.09.164.

[39] P. Lertwattanaruk, N. Makul, and C. Siripattarapravat, "Utilization of ground waste seashells in cement mortars for masonry and plastering," J. Environ. Manage., vol. 111, pp. 133-141, Nov. 2012, doi: 10.1016/J.JENVMAN.2012.06.032.

[40] W. Ten Kuo, H. Y. Wang, C. Y. Shu, and D. S. Su, "Engineering properties of controlled low-strength materials containing waste oyster shells," Constr. Build. Mater., vol. 46, pp. 128-133, Sep. 2013, doi: 10.1016/J.CONBUILDMAT.2013.04.020.

[41] F. Soltanzadeh, M. Emam-Jomeh, A. Edalat-Behbahani, and Z. Soltan-Zadeh, "Development and characterization of blended cements containing seashell powder," Constr. Build. Mater., vol. 161, pp. 292-304, Feb. 2018, doi: 10.1016/J.CONBUILDMAT.2017.11.111.

[42] N. H. Othman, B. H. A. Bakar, M. M. Don, and M. A. M. Johari, "COCKLE SHELL ASH REPLACEMENT FOR CEMENT AND FILLER IN CONCRETE," Malaysian J. Civ. Eng., vol. 25, no. 2, pp. 201-211, 2013, doi: 10.11113/MJCE.V25.15853.

[43] R. A. F. de Alvarenga, B. M. Galindro, C. de F. Helpa, and S. R. Soares, "The recycling of oyster shells: An environmental analysis using Life Cycle Assessment," J. Environ. Manage., vol. 106, pp. 102-109, Sep. 2012, doi: 10.1016/j.jenvman.2012.04.017.

[44] M. Azmi and M. Johari, "Cockle shell ash replacement for cement and filler in concrete," 2013. Accessed: May $28,2021$. [Online]. Available: https://www.researchgate.net/publication/309186729.

[45] ASTM C-150, “ASTM C150 - 07 Standard Specification for Portland Cement,” $2007,2007$. https://www.astm.org/DATABASE.CART/HISTORICAL/C150-07.htm (accessed May 08, 2021).

[46] B. Alsubari, P. Shafigh, and M. Z. Jumaat, "Development of Self-Consolidating High Strength Concrete Incorporating Treated Palm Oil Fuel Ash," Mater. 2015, Vol. 8, Pages 2154-2173, vol. 8, no. 5, pp. 2154-2173, Apr. 2015, doi: 10.3390/MA8052154.

[47] "What Happens When You Add Vinegar to Seashells?," sciencing, 2018. https://sciencing.com/happens-add-vinegar-seashells8411192.html (accessed Jul. 27, 2021).

[48] M. Olivia, R. Oktaviani, and Ismeddiyanto, "Properties of Concrete Containing Ground Waste Cockle and Clam Seashells," Procedia Eng., vol. 171, pp. 658-663, Jan. 2017, doi: 10.1016/J.PROENG.2017.01.404.

[49] D. Koteswara Rao and S. Vineela, "A LABORATORY STUDY ON THE PERFORMANCE OF EXPANSIVE SOIL SUBGRADE TREATED WITH SEASHELL POWDER AND FERRIC CHLORIDE," Int. J. Tech. Innov. Mod. Eng. Sci. Impact, vol. 4, no. 08, 2018.

[50] M. R. Karim, M. F. M. Zain, M. Jamil, F. C. Lai, and M. N. Islam, "Strength development of mortar and concrete containing fly ash: A review," Int. J. Phys. Sci., vol. 6, no. 17, pp. 4137-4153, 2011, doi: 10.5897/IJPS11.232.

[51] "ASTM C109 / C109M - 20b Standard Test Method for Compressive Strength of Hydraulic Cement Mortars (Using 2-in. or [50 mm] Cube Specimens)." https://www.astm.org/Standards/C109 (accessed Jul. 29, 2021).

[52] A. Ahmad, A. Pekrioglu Balkis, and K. Kurtis Onochie, "The use of shredded plastic wastes in Alker production and its effect on compressive strength and shrinkage properties," Alexandria Eng. J., Jun. 2021, doi: 10.1016/J.AEJ.2021.06.062.

[53] H. Ö. Öz, N. Doğan-Sağlamtimur, A. Bilgil, A. Tamer, and K. Günaydin, "Process Development of Fly Ash-Based Geopolymer Mortars in View of the Mechanical Characteristics," Mater. 2021, Vol. 14, Page 2935, vol. 14, no. 11, p. 2935, May 2021, doi: 10.3390/MA14112935.

[54] M. N. F. Ishak, N. H. Othman, and M. S. Sainudin, "A Review: Effects Of Mussel Shell Ash As Concrete Mixture Under Sodium Chloride Exposure," Recent Trends Civ. Eng. Built Environ., vol. 2, no. 1, pp. 824-833, Jun. 2021, Accessed: Aug. 06, 2021. [Online]. Available: https://publisher.uthm.edu.my/periodicals/index.php/rtcebe/article/view/1458.

[55] B. S. Thomas, S. Kumar, and H. S. Arel, "Sustainable concrete containing palm oil fuel ash as a supplementary cementitious material - A review," Renew. Sustain. Energy Rev., vol. 80, pp. 550-561, Dec. 2017, doi: 10.1016/J.RSER.2017.05.128.

[56] S. O. Bamaga, M. W. Hussin, and M. A. Ismail, "Palm Oil Fuel Ash: Promising supplementary cementing materials," KSCE J. Civ. Eng. 2013 177, vol. 17, no. 7, pp. 1708-1713, Oct. 2013, doi: 10.1007/S12205-013-1241-9.

[57] B. Alsubari, P. Shafigh, Z. Ibrahim, M. F. Alnahhal, and M. Z. Jumaat, "Properties of eco-friendly self-compacting concrete containing modified treated palm oil fuel ash," Constr. Build. Mater., vol. 158, pp. 742-754, Jan. 2018, doi: 10.1016/J.CONBUILDMAT.2017.09.174. 
[58] M. Safiuddin, M. A. Salam, and M. Z. Jumaat, "Key Fresh Properties of Self-Consolidating High-Strength POFA Concrete," J. Mater. Civ. Eng., vol. 26, no. 1, pp. 134-142, Jan. 2013, doi: 10.1061/(ASCE)MT.1943-5533.0000782.

[59] K. Muthusamy, N. A. Zamri, A. Kusbiantoro, N. H. A. S. Lim, and M. A. Mohd Ariffin, "Effect of palm oil fuel ash on compressive strength of palm oil boiler stone lightweight aggregate concrete," in IOP Conference Series: Materials Science and Engineering, Apr. 2018, vol. 342, no. 1, doi: 10.1088/1757-899X/342/1/012098.

[60] L. A. Sofri et al., "Performance of Concrete by Using Palm Oil Fuel Ash (POFA) as a Cement Replacement Material," Appl. Mech. Mater., vol. 815, pp. 29-33, Nov. 2015, doi: 10.4028/www.scientific.net/amm.815.29.

[61] M. Safiuddin, M. A. Salam, and M. Z. Jumaat, "Utilization of palm oil fuel ash in concrete: A review," Journal of Civil Engineering and Management, vol. 17, no. 2. pp. 234-247, 2011, doi: 10.3846/13923730.2011.574450.

[62] M. Olivia, A. A. Mifshella, and L. Darmayanti, "Mechanical properties of seashell concrete," in Procedia Engineering, 2015, vol. 125, pp. 760-764, doi: 10.1016/j.proeng.2015.11.127.

[63] M. Olivia, A. Arifandita Mifshella, and L. Darmayanti, "ScienceDirect Mechanical properties of seashell concrete," Procedia Eng., vol. 125, pp. 760-764, 2015, doi: 10.1016/j.proeng.2015.11.127.

[64] B. A. Tayeh, M. W. Hasaniyah, A. M. Zeyad, and M. O. Yusuf, "Properties of concrete containing recycled seashells as cement partial replacement: A review," Journal of Cleaner Production, vol. 237. Elsevier Ltd, Nov. 10, 2019, doi: 10.1016/j.jclepro.2019.117723.

[65] M. N. M. Sidek et al., "Utilisation of palm oil fuel ash (POFA) as cement replacement by using powder and liquidation technique," AIP Conf. Proc., vol. 2020, no. October 2018, 2018, doi: 10.1063/1.5062695.

[66] U. Tunku and A. Rahman, "ENGINEERING PROPERTIES OF LIGHTWEIGHT FOAMED CONCRETE INCORPORATED WITH PALM OIL FUEL ASH (POFA) YONG CHUN YIP A project report submitted in partial fulfilment of the requirements for the award of the degree of Bachelor (Hons.) of Civil Engineering Faculty of Engineering and Science," 2013.

[67] W. A. S. Bin Wan Mohammad, N. H. Othman, M. H. Wan Ibrahim, M. A. Rahim, S. Shahidan, and R. A. Rahman, "A review on seashells ash as partial cement replacement," in IOP Conference Series: Materials Science and Engineering, Dec. 2017, vol. 271, no. 1, p. 012059, doi: 10.1088/1757-899X/271/1/012059.

[68] W. Sanawung, T. Cheewaket, W. Tangchirapat, and C. Jaturapitakkul, "Influence of Palm Oil Fuel Ash and W/B Ratios on Compressive Strength, Water Permeability, and Chloride Resistance of Concrete," Adv. Mater. Sci. Eng., vol. 2017, 2017, doi: $10.1155 / 2017 / 4927640$.

[69] S. H. Adnan, M. A. S. Abadalla, and Z. Jamellodin, "The mechanical and physical properties of concrete containing polystyrene beads as aggregate and palm oil fuel ash as cement replacement material," AIP Conf. Proc., vol. 1891, no. 1, p. 020016, Oct. 2017, doi: 10.1063/1.5005349.

[70] J. Zhang, H. Chen, and Y. Pan, "IOP Conference Series: Earth and Environmental Science Research and Application of Shell Powder," IOP Conf. Ser. Earth Environ. Sci, vol. 170, p. 32031, 2018, doi: 10.1088/1755-1315/170/3/032031.

[71] B. P. Ong and U. Kassim, "Performance of Concrete Incorporating of Clam Shell as Partially Replacement of Ordinary Portland Cement (OPC)," J. Adv. Res. Appl. Mech. J. homepage, vol. 55, pp. 12-21, 2019, Accessed: Jun. 02, 2021. [Online]. Available: www.akademiabaru.com/aram.html. 